\title{
Effect of farming system and cheesemaking technology on the physicochemical characteristics, fatty acid profile, and sensory properties of Caciocavallo Palermitano cheese
}

\author{
A. Bonanno, ${ }^{*}$ G. Tornambè, ${ }^{* 1}$ V. Bellina, ${ }^{*}$ C. De Pasquale, $†$ F. Mazza, ${ }^{*}$ G. Maniaci, ${ }^{*}$ and A. Di Grigoli ${ }^{*}$ \\ *Dipartimento DEMETRA, Università degli Studi di Palermo, viale delle Scienze, 90128 Palermo, Italy \\ †Dipartimento dei Sistemi Agro-Ambientali (SAGA), Università degli Studi di Palermo, viale delle Scienze, 90128 Palermo, Italy
}

\begin{abstract}
Caciocavallo Palermitano is a typical stretched-curd cheese that has been produced over the centuries in Sicily according to traditional cheesemaking technology and using raw milk from autochthonous cow breeds reared at pasture. The objective of this experiment was to evaluate the effects of the farming system and processing technology on the characteristics of Caciocavallo Palermitano cheese, with particular regard to the fatty acid profile. The farming system was either extensive, using autochthonous cows fed a pasture-based diet, or intensive, with specialized dairy cow breeds fed mainly hay and concentrate. The cheese-processing technology was either artisanal, using traditional wooden tools and endemic lactic bacteria, or advanced, using modern steel equipment and selected lactic bacteria. Twelve Caciocavallo Palermitano cheeses, 3 from each of the 4 experimental theses $(2$ farming systems $\times 2$ cheesemaking technologies), were obtained and aged for 1, 30, 60, and $120 \mathrm{~d}$. Milk of origin and cheeses were analyzed for the main chemical and rheological parameters. Fatty acids were methylated in lyophilized cheese and analyzed by gas chromatography. Sensory analysis was carried out by trained panelists. The PROC GLM of SAS 9.1.2 (SAS Institute Inc., Cary, NY) was used for the statistical analysis. The physical, chemical, and sensory characteristics of Caciocavallo Palermitano cheese were influenced more by the farming system than by the cheesemaking technology. Compared with cheese produced through intensive farming, cheese from extensive farming was richer in polyunsaturated, n-3, and odd- and branched-chain fatty acids, as well as in conjugated linoleic acid (cis-9,trans-11 C18:2), with accompanying improved human health benefits. The cheesemaking technology produced variation in the evolution of proteolysis during aging, due presumably to the different active microflora, which influenced the
\end{abstract}

Received July 24, 2012.

Accepted September 15, 2012.

${ }^{1}$ Corresponding author: gabriele.tornambe@unipa.it sensory profile of the resulting cheese. Indeed, cheese produced by artisanal manufacturing was described as less "bitter" and more "piquant" than cheese produced through the advanced process.

Key words: autochthonous cow breed, artisanal cheesemaking, fatty acid, sensory profile

\section{INTRODUCTION}

Caciocavallo Palermitano is a typical stretched-curd (pasta filata) cheese. Its presence in the markets of Palermo, in Western Sicily (Italy), has been well documented since 1412. Papers dating to 1500 and 1679 claim it was primarily used in the diets of religious communities and noble families in Palermo (Bonanno, 2006). Caciocavallo Palermitano is produced using whole and raw cow milk from both early morning and evening milking. The cheese has a firm paste and a characteristic parallelepiped shape. As the cheese matures, its distinctive straw-colored hue changes to an ochre color (Bonanno et al., 2004). Caciocavallo Palermitano is historically linked to indigenous inland farming cow breeds, especially Cinisara, that are able to productively exploit the natural pasture of the hills and semi-arid areas of the Sicilian island (Di Grigoli et al., 2008; Tornambè et al., 2009). Therefore, this cheese is traditionally produced by small farms using local cows fed at pasture, according to an artisanal manufacturing procedure based on the use of wooden tools and the action of specific native microflora (Settanni et al., 2012). More recently, this dairy product has been produced by more intensive farming systems. These farms rear specialized breeds of dairy cows with high milk yield and, in compliance with the European Union rules regarding the requirements of dairy factories, use a more advanced cheesemaking processes using stainless steel equipment and commercial starter culture.

Cheese-quality traits are affected by many factors, such as the genetic characteristics of animals (breed) (Ferlay et al., 2006), feeding (pasture, fresh, or preserved forage, and the botanical composition of herbage; Bonanno et al., 2004; Tornambé et al., 2005, 2007), 
and the microbial activity in milk and cheese, especially during ripening. All these aspects were reviewed in detail by Coulon et al. (2004), with particular attention to the sensory characteristics of cheeses.

Studies focusing on other Sicilian cheeses, such as Ragusano (a stretched-curd cheese from cow milk; Carpino et al., 2004; Fallico et al., 2005) and Piacentinu Ennese and Pecorino Siciliano (pressed cheeses from ewe milk; Horne et al., 2004; Carpino et al., 2008; Todaro et al., 2011), have found that traditional technologies using wooden tools, covered by native microflora biofilm, affect the quality characteristics of cheese. Other recent studies have investigated the functional components of milk and industrial and traditional cheese, particularly FA. Polyunsaturated FA, including conjugated linoleic acids (CLA) and n-3 FA, have been shown to have a positive effect on human health (Banni et al., 2002), especially in relation to their potential anticarcinogenic properties (McGuire and McGuire, 2000) and in the prevention of heart disease (Belury, 2002). Despite its undeserved reputation for being unhealthy, cheese has been rediscovered as a potential natural source of these healthy nutraceutical components. Compared with animals in intensive farming systems fed hay and silage, extensively farmed ruminants fed green forage at pasture produce milk and cheese that is richer in PUFA and CLA (Chilliard et al., 2007). The abundance of these components increases proportionally with the amount of the fresh forage ingested (Couvreur et al., 2006; Ferlay et al., 2008). Particularly when they are fed green forage, the cows of autochthonous breeds produce milk that is richer in PUFA than is the milk from specialized dairy cows (Ferlay et al., 2006; Martin et al., 2009).

The objective of this experiment was to evaluate the effects of the farming system (extensive vs. intensive) and the processing technology (traditional, using artisanal wooden tools and endemic lactic bacteria, versus advanced, using modern steel equipment and selected lactic bacteria) on the characteristics of Caciocavallo Palermitano cheese.

\section{MATERIALS AND METHODS}

\section{Preexperimental Trial}

During the year before the experimental trial, 22 farms, located in the typical area of Caciocavallo Palermitano production, were investigated with regard to farm management and cheesemaking practices. In 11 of the 22 farms, 1-mo aged Caciocavallo Palermitano cheeses were sampled. In 6 of these farms, representing the traditional (TRD) group, cows from local Cinisara and Modicana breeds, or derived from these breeds, were fed a pasture-based diet; cheese was manufactured using artisanal wooden tools and following the traditional technique. In the 5 other farms, representing the innovative (INN) group, cows from specialized breeds such as Brown or Holstein were fed mostly hay and concentrate; a more advanced and rapid cheesemaking process, implemented with the modern steel tools, was used. The sampled 1-mo aged Caciocavallo cheeses were processed for physical, chemical, and FA analysis.

\section{Experimental Trial and Cheesemaking}

An experimental trial was set up to obtain representative cheeses from different systems of milk production and cheesemaking technologies. Bulk milk was collected 3 times from each of 2 farms located in the Caciocavallo Palermitano production region. Extensive (EXT) milk was obtained from a farm where an autochthonous cow breed (Cinisara) was fed mainly at pasture, with hay supplementation at night. Intensive (INT) milk was obtained from Brown cows fed hay and concentrate with a very small proportion of pasture. For every collection, bulk milk was transported to a cheese factory where it was divided into 2 aliquots, one processed according to the artisanal procedure using wooden tools (ART) and the other according to an advanced and rapid cheesemaking process (ADV) with modern steel equipment. Twelve Caciocavallo Palermitano cheeses were obtained, 6 from each process.

The traditional Caciocavallo Palermitano cheesemaking process lasts $2 \mathrm{~d}$ (Figure 1). The first day, raw milk collected during the prior $24 \mathrm{~h}$ is added at $35 / 37^{\circ} \mathrm{C}$ with a lamb rennet paste in a wood vat (tina). After 40 to $50 \mathrm{~min}$, coagulated curd is broken with a wood tool (rotula) and then separated from whey using also the pressure exerted by a traditional wooden bowl (cisca). The curd is cut into big slices and placed on a plane made with natural reeds to eliminate residual whey. The curd slices are then put back into the tina and covered by hot whey (about $80^{\circ} \mathrm{C}$ ) from ricotta cheese fabrication for about $3 \mathrm{~h}$. At the end of cooking, the cheesemaker presses the curd to remove the whey, and hangs it on a stick until the following day. During this time, the action of lactic microbial flora acidifies the caseous mass. On the second day, the acidified mass is cut along the stretch lines into slices of about 100 to $200 \mathrm{~g}$ and placed in a truncated conical wooden vat (piddiaturi); here the mass is covered by ricotta whey at $80^{\circ} \mathrm{C}$ and stretched with a wooden stick (maciliatuma). Finally, air and residual whey are eliminated from the caseous mass by typical manual work (accuppatina), and the cheese is placed in a wooden form (tavuleri) where it acquires the typical parallelepiped form. On the third day, the cheese is dropped in a saturated brine 


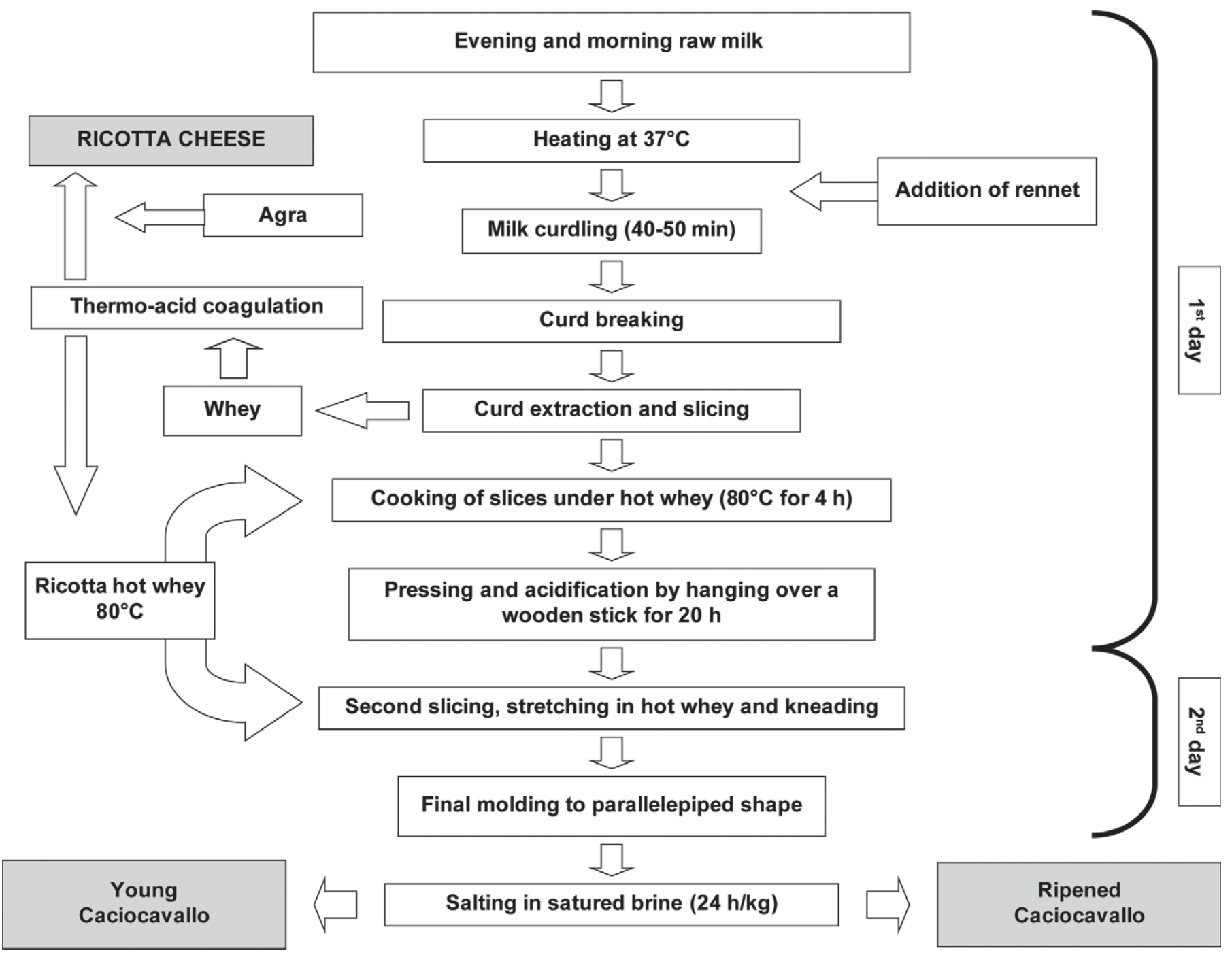

Figure 1. Flow diagram of traditional Caciocavallo Palermitano cheesemaking.

where is kept for $1 \mathrm{~d} / \mathrm{kg}$. Semi-ripened Caciocavallo Palermitano can be aged from 2 to 4 mo; ripened cheese is aged for more than 4 mo.

The ART cheeses were obtained following the described procedure. The raw milk is not treated with high temperature nor is microflora starter added. Rather, lactic acid bacteria, which form a biofilm on the surface of the wooden tina [analyzed and described in a parallel study by Settanni et al. (2012)], are released in the milk, enriching its natural microflora.

The ADV cheeses were produced from raw milk through modern cheesemaking technology, using exclusively stainless steel and plastic equipment. In the process, a commercial freeze-dried starter preparation (LYOBAC-D T; Alce International S.r.l., Quistello, Italy) was added to raw milk. All of the cheeses were ripened up to $120 \mathrm{~d}$ in controlled conditions at a temperature of 14 to $16^{\circ} \mathrm{C}$ and constant humidity.

\section{Measurements, Sampling, and Analysis}

Raw whole milk was sampled and analyzed for lactose, fat, protein, and casein content, as well as SCC (CombiFoss 6000; Foss Electric A/S, Hillerød, Denmark), total bacterial count (BactoScan; Foss Electric A/S), urea (CL-10 Plus; Eurochem S.r.l., Rome, Italy), pH (HI 9025 pH meter; Hanna Instruments Inc., Ann Arbor, MI), and titratable acidity [Soxhlet-Henkel degrees $\left.\left({ }^{\circ} \mathrm{SH}\right) / 50 \mathrm{~mL}\right]$. Bulk milk was also evaluated for clotting ability by measuring clotting time (r, min), curd-firming time $\left(\mathrm{k}_{20}, \mathrm{~min}\right)$, and curd firmness $\left(\mathrm{a}_{30}\right.$, $\mathrm{mm}$; Formagraph; Foss Electric A/S). 
Cheeses aged for $1,30,60$, and $120 \mathrm{~d}$ were sampled from the same form. With every sampling, the cut surface was covered by paraffin to permit continued aging. For each aged sample, $\mathrm{DM}$, fat, protein $(\mathrm{N} \times 6.38)$, and ash content were determined according to International Dairy Federation (IDF) standards [4A:1982 (IDF, 1982), 5B:1986 (IDF, 1986), 25:1964 (IDF, 1964a), and 27:1964 (IDF, 1964b), respectively]. In addition, soluble nitrogen $(\mathrm{N})$ content was determined on an aqueous filtrate using the Kjeldahl method (MAF, 1986), and $\mathrm{NaCl}$ according to the IDF procedure (17A:1972; IDF, 1972)

Color was measured by Minolta Chroma Meter (CR-300; Minolta, Osaka, Japan) using illuminant C. Results are expressed as lightness $\left(\mathbf{L}^{*}\right)$, redness $\left(\mathbf{a}^{*}\right)$, and yellowness $\left(\mathbf{b}^{*}\right)$, according to the International Commission on Illumination (CIE) $\mathrm{L}^{*} \mathrm{a}^{*} \mathrm{~b}^{*}$ system. The maximum resistance to compression (compressive stress, $\mathrm{N} / \mathrm{mm}^{2}$ ) was measured with an Instron 5564 tester (Instron, Trezzano sul Naviglio, Milano, Italy).

Fatty acids in lyophilized cheese samples (100 mg) were directly methylated with $2 \mathrm{~mL}$ of $0.5 \mathrm{M} \mathrm{NaOCH}_{3}$ at $50^{\circ} \mathrm{C}$ for $15 \mathrm{~min}$, followed by $1 \mathrm{~mL}$ of $5 \% \mathrm{HCl}$ in methanol at $50^{\circ} \mathrm{C}$ for 15 min (Loor et al., 2002). Fatty acid methyl esters (FAME) were recovered in hexane $(1.5 \mathrm{~mL})$. One microliter of each sample was injected by autosampler into an HP 6890 gas chromatography system equipped with a flame-ionization detector (Agilent Technologies Inc., Santa Clara, CA). Fatty acid methyl esters from all samples were separated using a 100-m length, $0.25-\mathrm{mm}$ i.d., $0.25-\mu \mathrm{m}$ capillary column (CP-Sil 88; Chrompack, Middelburg, the Netherlands). The injector temperature was kept at $255^{\circ} \mathrm{C}$ and the detector temperature was kept at $250^{\circ} \mathrm{C}$, with an $\mathrm{H}_{2}$ flow of 40 $\mathrm{mL} / \mathrm{min}$, air flow of $400 \mathrm{~mL} / \mathrm{min}$, and a constant $\mathrm{He}$ flow of $45 \mathrm{~mL} / \mathrm{min}$. The initial oven temperature was held at $70^{\circ} \mathrm{C}$ for $1 \mathrm{~min}$, increased at $5^{\circ} \mathrm{C} / \mathrm{min}$ to $100^{\circ} \mathrm{C}$, held for $2 \mathrm{~min}$, increased at $10^{\circ} \mathrm{C} / \mathrm{min}$ to $175^{\circ} \mathrm{C}$, held for $40 \mathrm{~min}$, and then finally increased at $5^{\circ} \mathrm{C} / \mathrm{min}$ to a final temperature of $225^{\circ} \mathrm{C}$ and held for $45 \mathrm{~min}$. Helium, with a head pressure of $158.6 \mathrm{kPa}$ and a flow rate of $0.7 \mathrm{~mL} / \mathrm{min}$ (linear velocity of $14 \mathrm{~cm} / \mathrm{s}$ ), was used as the carrier gas. Fatty acid methyl ester hexane mix solution (Nu-Chek Prep Inc., Elysian, MN) was used to identify each FA. The identification of CLA isomers was performed using a commercial mixture of cis- and trans-9,11- and 10,12-ocdecadienoic acid methyl esters (Sigma-Aldrich, Milano, Italy). To quantify total FA, C23:0 (Sigma-Aldrich) was added to each sample (4 $\mathrm{mg} / \mathrm{g}$ of lyophilized cheese) as the internal standard. The health-promoting index (HPI) was calculated as suggested by Chen et al. (2004): total unsaturated FA/ $[\mathrm{C} 12: 0+(4 \times \mathrm{C} 14: 0)+\mathrm{C} 16: 0]$.

\section{Sensory Analysis}

Cheeses ripened for 30 and $60 \mathrm{~d}$, corresponding to 24 samples $(2$ farming systems $\times 2$ cheesemaking technologies $\times 3$ replicates $\times 2$ ripening times), were evaluated by each of 12 trained panelists in 6 sessions, according to Tornambé et al. (2008) and Depledt and SSHA (2009). In each session, 2 pieces of 4 different cheeses were cut and presented at room temperature $\left(20^{\circ} \mathrm{C}\right)$ under red light to the panelists, who were in individual cubicles. The first piece of cheese was evaluated on the basis of specific attributes defined for the Caciocavallo Palermitano cheese by the same panelists in 2 preliminary sensory test sessions, with regard to the texture (smooth, hard, unctuous, or elastic) and the taste (sweet, bitter, salty, acid, or piquant). Each panelist then visually analyzed the second piece of cheese under natural light for the presence of holes, the thickness of the under-rind, and the color of paste, rind, and under-rind. All of the sensory attributes were evaluated on an 8-point graduated scale from 0 (very low) to 7 (very high).

\section{Data Analysis}

The GLM procedure of SAS 9.1.2 (SAS Institute, 2004) was used for the statistical analysis, considering farm $(\mathbf{F M})$, cheesemaking technology (CMT), ripening time $(\mathbf{R T})$, and the interactions $\mathrm{FM} \times \mathrm{CMT}, \mathrm{FM}$ $\times \mathrm{RT}$, and CMT $\times \mathrm{RT}$ as fixed factors. For the sensory analysis, the effect of the panelists was also introduced into the model. Means were compared using the Student's $t$-test.

\section{RESULTS AND DISCUSSION}

\section{Preexperimental Trial}

Chemical and physical cheese characteristics showed high variability within each farming system, and did not significantly differ between TRD and INN farms. Nevertheless, TRD cheeses showed a slightly higher DM content and a higher resistance in the compression test (Table 1), which seems to indicate that traditional wood equipment and native microflora produce a firmer curd.

However, the TRD cheeses, produced from the milk of pasture-fed animals, had a better FA composition than INN cheeses (Table 1). In fact, cheeses from INN farms had a higher SFA content $(P<0.01)$, particularly because of their higher concentration of palmitic acid $(\mathrm{C} 16: 0 ; P<0.01)$. The TRD cheeses were richer in unsaturated FA $(P<0.01)$, as a consequence of their higher (but not significantly higher) oleic acid (cis-9 
Table 1. Preexperimental cheeses: DM, compressive stress, and FA composition (\% of FA methyl esters) in relation to producing system

\begin{tabular}{lccc} 
& \multicolumn{2}{c}{ Producing system ${ }^{1}$} & \\
\cline { 2 - 3 } Item & TRD & INN & Significance $^{2}$ \\
\hline DM, \% & 61.9 & 58.9 & NS \\
Fat, \% of DM & 40.1 & 37.5 & NS \\
Compressive stress, N/mm ${ }^{2}$ & 0.20 & 0.14 & NS \\
FA composition & & & \\
SFA & 66.5 & 69.9 & $* *$ \\
MUFA & 28.1 & 25.6 & + \\
PUFA & 5.44 & 4.53 & NS \\
Unsaturated FA & 33.1 & 30.1 & $* *$ \\
SFA/unsaturated FA & 0.50 & 0.44 & $* *$ \\
C16:0 & 26.48 & 31.03 & $* *$ \\
cis-9 C18:1 & 20.96 & 19.34 & NS \\
cis-9, trans-11C18:2 CLA (RA) & 1.15 & 0.67 & $*$ \\
C18:3n-3 & 1.39 & 1.05 & NS \\
n-6/n-3 & 1.54 & 2.40 & + \\
OBCFA & 5.22 & 4.73 & $*$ \\
HPI & & & $*$ \\
\hline
\end{tabular}

${ }^{1} \mathrm{TRD}=$ traditional; INN $=$ innovative.

${ }^{2} \mathrm{NS}$ indicates $P>0.10$.

${ }^{3} \mathrm{CLA}=$ conjugated linoleic acid; RA = rumenic acid.

${ }^{4} \mathrm{OBCFA}=$ odd- and branched-chain FA.

${ }^{5} \mathrm{HPI}=$ health-promoting index $=$ unsaturated $\mathrm{FA} /(\mathrm{C} 12: 0+4 \times$ C14:0 + C16:0) (Chen et al., 2004).

${ }^{* *} P \leq 0.01 ; * P \leq 0.05 ;+$ indicates $P \leq 0.10$;

C18:1) and $\alpha$-linolenic acid (C18:3n-3) content, and significantly higher content of rumenic acid (cis-9,trans-11 C18:2 CLA; $P<0.05$ ), which was almost double that of INN cheeses. This larger amount of unsaturated FA and CLA in TRD cheeses is in accordance with the enrichment in $\alpha$-linolenic acid, CLA, and MUFA and PUFA observed in milk from cows transitioned from preserved feeds to a pasture-based diet (Chilliard et al., 2001). Notably, TRD cheeses were also characterized by a higher content of odd- and branched-chain FA (OBCFA; $P<0.05$ ), in line with Vlaeminck et al. (2006), who reported an increase in OBCFA in milk when dietary forage content increased. Finally, TRD cheeses were characterized by a slightly lower and more favorable n-6:n-3 ratio $(P<0.10)$ and a higher HPI than INN cheeses $(P<0.01)$, indicating a less detrimental effect on human health.

\section{Experimental Trial}

Farm System. Milk quality was affected by the farming system. Extensive milk was richer $(P<0.001)$ in lactose, protein, and casein and lower $(P<0.001)$ in fat, urea, and somatic cells. No significant differences were observed in the coagulation parameters (Table 2).

Cows from autochthonous breeds are known to produce less milk than cows from specialized breeds (Licitra et al., 1998), in part because they are reared in traditional farming systems where their feeding is based on the almost exclusive exploitation of natural pasture, often without concentrate supplementation. As a consequence, autochthonous cows generally produce more concentrated milk than specialized cow breeds. In this trial, milk protein and casein followed this trend, whereas fat was less concentrated, despite the animals' pasture-based diet, which had a high forage-to-concentrate ratio and, thus, was richer in fiber, promoting an increase in milk fat (Bauman and Griinari, 2001). The lower milk fat of autochthonous cows is probably linked to the milking system. To stimulate the release of oxytocin by the pituitary and the resulting emission of the milk by the udders, milking is traditionally done in the presence of the calf; the last milk produced during milking, which is richer in fat, is normally reserved for the calf, thus lowering the fat level in the milked milk (Alabiso et al., 2000; Combellas and Tesorero, 2003).

The higher urea level in INT milk is an indicator of a higher daily protein intake and the higher ratio of dietary protein to energy intake by INT cows (Schepers and Meijer, 1998). The lower SCC in the milk from autochthonous cows may result from the effect of grazing at pasture in reducing the stress of animals, as well as in reducing the animals' permanent housing in the stable and, accordingly, the time of contact between the udder and the litter; this situation, coupled with the major resistance of autochthonous cows in comparison with specialized dairy cow breeds, protects the udders from mastitis, contributing to lower SCC levels.

The farming system affected the yield, chemical composition, and color parameters $\left(\mathrm{L}^{*}, \mathrm{a}^{*}\right.$, and $\left.\mathrm{b}^{*}\right)$ of cheeses, but did not influence the resistance of cheese

Table 2. Milk composition and clotting parameters

\begin{tabular}{lccc}
\hline & \multicolumn{2}{c}{ Farm $^{1}$} & \\
\cline { 2 - 3 } Item & EXT & INT & \\
\hline Lactose, $\%$ & 5.21 & 4.86 & $* * *$ \\
Fat, $\%$ & 3.35 & 3.80 & $* * *$ \\
Protein, $\%$ & 3.65 & 3.39 & $* * *$ \\
Casein, $\%$ & 2.84 & 2.54 & $* * *$ \\
Urea, $\mathrm{mg} / \mathrm{dL}$ & 31.7 & 43.9 & $* * *$ \\
SCC, $\log _{10} 1,000 / \mathrm{mL}$ & 5.28 & 5.88 & $* * *$ \\
Total bacterial count, $\log _{10} 1,000 / \mathrm{mL}$ & 5.83 & 6.39 & NS \\
pH & 6.73 & 6.82 & + \\
Titratable acidity ${ }^{2}{ }^{\circ} \mathrm{SH} / 50 \mathrm{~mL}$ & 3.75 & 3.22 & NS \\
Clotting time $(\mathrm{r}), \mathrm{min}$ & 18.6 & 15.3 & NS \\
Curd-firming time $\left(\mathrm{k}_{20}\right), \mathrm{min}$ & 3.42 & 4.19 & NS \\
Curd firmness $\left(\mathrm{a}_{30}\right), \mathrm{min}$ & 28.5 & 29.7 & NS \\
\hline
\end{tabular}

${ }^{1} \mathrm{EXT}=$ extensive, where an autochthonous cow breed (Cinisara) was fed mainly at pasture, with hay supplementation at night; INT = intensive, where Brown cows were fed hay and concentrate with a very small proportion of pasture.

${ }^{2 \circ} \mathrm{SH}=$ Soxhlet-Henkel degrees.

*** $P \leq 00001 ;+$ indicates $P \leq 0.10$. 
to compression (Table 3). In fact, compared with INT cheeses, those produced in the EXT farm had a higher yield and protein content but lower levels of fat, $\mathrm{NaCl}$, and soluble N; the EXT cheeses also had a less intense yellow color, indicated by a lower $\mathrm{b}^{*}$ value.

The higher cheese yield of milk from the EXT farm $(P<0.001)$ was linked to the higher casein content of EXT milk (Table 2). Moreover, milk from rustic autochthonous Sicilian cows has a very high frequency of $\kappa-\mathrm{CN}$ and $\beta$-LG alleles that improve the cheesemaking properties of milk and the final cheese yield (Campo et al., 1999; Guastella et al., 2006).

Cheese fat was lower in EXT samples than INT samples $(P<0.001)$, following the same trend observed for the respective milks. As previously noted, this result is probably because in autochthonous cows, the last - and most fat-rich-milk derived from milking is normally destined for the calf.

The higher $\mathrm{NaCl}$ content in INT than EXT cheeses $(P<0.001)$ may have been caused by their lower moisture levels, which concentrated the salt. Soluble N was significantly higher in cheese from INT milk than in EXT cheese (Table 3), probably reflecting the difference in milk urea that emerged between farms (Table 2), as observed by Martin et al. (1997)

Finally, the higher yellow index $\left(b^{*}\right)$ value of cheeses from INT milk $(P<0.001)$ was probably due to a higher level of carotenoids in the maize-based concentrate consumed by the animals in the intensive system, although the cow breed may also have had an influence (Nozière et al., 2006).

Cheesemaking Technology. Cheesemaking technology affected the cheese yield, chemical composition, and color. Indeed, compared with ADV technology, ART technology reduced cheese yield $(P<0.01)$, mainly because these cheeses had lower moisture content; the lower protein levels $(P<0.01)$ of ART cheeses corresponded to an increase in fat content $(P<0.001$; Table $3)$. The ADV cheeses were higher in $\mathrm{NaCl}$ and soluble $\mathrm{N}(P<0.001)$. The higher $\mathrm{NaCl}$ level was attributable to the higher moisture level of the paste, favoring salt absorption by osmosis; the salt level was also affected by the interaction between farm and technology, with ADV technology producing cheeses that were higher in salt than those made by ART manufacturing, although only when applied to milk from the EXT farm (3.13 vs. $2.01 \mathrm{~g} / 100 \mathrm{~g} ; P<0.001)$. The higher soluble $\mathrm{N}$ in cheeses from the ADV procedure represented the more pronounced proteolysis (Fallico et al., 2004) induced by the selected acid lactic bacteria compared with the indigenous microorganisms active in the ART cheeses.

The ART cheeses also had higher values $(P<0.001)$ for the $\mathrm{L}^{*}$ and $\mathrm{a}^{*}$ and $\mathrm{b}^{*}$ color indexes (Table 3 ).
Chatelain et al. (2003) suggested that microflora play a direct role in changing the cheese color and Buffa et al. (2001) proposed that by changing the structure of cheese, microflora indirectly influence the color indexes. Therefore, the indigenous lactic microorganisms present in the biofilm on the wooden tools used during ART cheesemaking (Settanni et al., 2012) and their relative activity during aging, could produce these different color values.

Finally, ART cheeses were twice as resistant to compression as ADV cheeses, indicating a more compact cheese paste. This result confirms the observation in the preexperimental trial that the wooden tools and native microflora used in ART technology produce more compact cheese paste. In fact, during ART cheese making, strong pressure is exerted on the cheese paste to eliminate the residual whey; through this process, an acidified dried curd is obtained that, after stretching, is more compact than the cheeses produced through ADV technology, which does not involve this pressure action (Tornambè et al., 2009). Moreover, the lower moisture and harder consistency of ART cheese could explain its lower $\mathrm{NaCl}$ content, because these could have prevented salt penetration into the cheese.

A significant interaction between farm system and cheesemaking technology also was observed for protein percentage and color parameters $\left(\mathrm{L}^{*}\right.$ and $\left.\mathrm{a}^{*}\right)$. Indeed, in contrast to EXT cheeses, cheeses from the INT farm produced by ART cheese making had lower protein levels than ADV cheeses, (47.4 vs. $49.6 \%$ DM; $P<0.05$ ), whereas ADV cheeses had lower brightness (L*: 76.4 vs. 83.7; $P<0.001)$ and red indexes (a* -5.45 vs. -4.48 ; $P<0.01)$ than ART cheeses.

Ripening Time. With regard to the effect of cheese ripening time (Table 3), a significant time trend was observed for almost all cheese parameters. However, between 30 and $60 \mathrm{~d}$ of aging, an unexpected reduction in both $\mathrm{DM}$ and $\mathrm{NaCl}$ content emerged. This contrasted with other observations on Ragusano cheese, in which cheese moisture was directly correlated to salt content (Fallico et al., 2004), and Parmigiano Reggiano cheese, in which both DM and salt content increased during ripening, although higher moisture and lower $\mathrm{NaCl}$ were found in the core rather than the external section of the cheese, because their uniformity is not reached until between 10 and 15 mo of ripening (Panari et al., 2003; Tosi et al., 2008). The opposite DM and $\mathrm{NaCl}$ trends in the cheeses studied here may be related to the adopted sampling method. Because of the paraffin covering, the exposure of the central slice of cheese to the air was reduced, which may have slowed down dehydration and $\mathrm{NaCl}$ penetration into the $60-\mathrm{d}$ aged cheese samples. With this in mind, it is notable that 
Table 3. Cheese composition and physical characteristics

\begin{tabular}{|c|c|c|c|c|c|c|c|c|c|c|c|c|c|c|}
\hline \multirow[b]{2}{*}{ Item $^{1}$} & \multicolumn{2}{|c|}{ Farm $(\mathrm{FM})^{2}$} & \multicolumn{2}{|c|}{$\begin{array}{c}\text { Cheesemaking } \\
\text { technology }(\mathrm{CMT})^{3}\end{array}$} & \multicolumn{4}{|c|}{ Ripening time (RT), d } & \multicolumn{6}{|c|}{ Significance } \\
\hline & EXT & INT & $\mathrm{ART}$ & $\mathrm{ADV}$ & 1 & 30 & 60 & 120 & FM & CMT & $\mathrm{RT}$ & $\begin{array}{l}\mathrm{FM} \times \\
\mathrm{CMT}\end{array}$ & $\begin{array}{c}\mathrm{FM} \times \\
\mathrm{RT}\end{array}$ & $\begin{array}{l}\mathrm{CMT} \\
\times \mathrm{RT}\end{array}$ \\
\hline Cheese vield, \% & 8.98 & 7.86 & 8.20 & 8.63 & 8.88 & 8.49 & 8.29 & 8.01 & $* * *$ & ** & $* * *$ & NS & NS & NS \\
\hline DM, \% & 58.4 & 60.6 & 61.6 & 57.4 & $52.7^{\mathrm{D}}$ & $61.9^{\mathrm{B}}$ & $60.0^{\mathrm{C}}$ & $63.5^{\mathrm{A}}$ & $* * *$ & $* * *$ & $* * *$ & + & $* *$ & NS \\
\hline Protein, $\%$ of DM & 49.6 & 48.5 & 48.4 & 49.7 & $51.0^{\mathrm{A}}$ & $48.1^{\mathrm{B}}$ & $48.6^{\mathrm{B}}$ & $48.5^{\mathrm{B}}$ & $* *$ & $* *$ & $* * *$ & $*$ & NS & NS \\
\hline Fat, $\%$ of DM & 38.9 & 40.5 & 40.7 & 38.7 & 40.3 & 39.2 & 39.6 & 39.8 & $* *$ & $* * *$ & NS & NS & NS & NS \\
\hline Ash, $\%$ of DM & 7.74 & 7.92 & 7.40 & 8.26 & $5.01^{\mathrm{C}}$ & $9.33^{\mathrm{A}}$ & $8.06^{\mathrm{B}}$ & $8.91^{\mathrm{A}}$ & NS & $* * *$ & $* * *$ & + & NS & + \\
\hline $\mathrm{NaCl}, \mathrm{g} / 100 \mathrm{~g}$ & 2.57 & 3.16 & 2.56 & 3.18 & & $3.27^{\mathrm{A}}$ & $2.31^{\mathrm{B}}$ & $3.01^{\mathrm{A}}$ & $* * *$ & *** & $* * *$ & $* * *$ & NS & NS \\
\hline Soluble N, $\%$ of DM & 0.90 & 1.05 & 0.76 & 1.19 & $0.48^{\mathrm{D}}$ & $0.88^{\mathrm{C}}$ & $1.18^{\mathrm{B}}$ & $1.36^{\mathrm{A}}$ & $*$ & $* * *$ & $* * *$ & NS & NS & $*$ \\
\hline $\mathrm{SN} / \mathrm{TN}$ & 11.6 & 13.9 & 10.0 & 15.5 & $6.01^{\mathrm{C}, \mathrm{d}}$ & $11.65^{\mathrm{B}, \mathrm{c}}$ & $15.51^{\mathrm{A}, \mathrm{b}}$ & $17.93^{\mathrm{A}, \mathrm{a}}$ & * & $* * *$ & $* * *$ & NS & NS & * \\
\hline $\mathrm{L}^{*}$ & 81.4 & 80.1 & 83.0 & 78.4 & & $82.5^{\mathrm{A}}$ & $81.8^{\mathrm{A}}$ & $77.9^{\mathrm{B}}$ & * & $* * *$ & $* * *$ & $* * *$ & NS & NS \\
\hline$a^{*}$ & -4.63 & -4.97 & -4.48 & -5.11 & & $-4.55^{\mathrm{A}}$ & $-4.46^{\mathrm{A}}$ & $-5.38^{\mathrm{B}}$ & $* *$ & $* * *$ & $* * *$ & $* *$ & NS & NS \\
\hline $\mathrm{b}^{*}$ & 26.6 & 30.0 & 29.4 & 27.2 & & 27.8 & 28.4 & 28.7 & $* * *$ & $* * *$ & NS & NS & NS & $* *$ \\
\hline Compressive stress, $\mathrm{N} / \mathrm{mm}^{2}$ & 0.240 & 0.236 & 0.309 & 0.168 & & 0.202 & 0.205 & 0.309 & NS & $* * *$ & $*$ & NS & NS & NS \\
\hline
\end{tabular}

$\overline{\mathrm{A}-\mathrm{D}}$ Means within a row with different superscripts differ $(P \leq 0.01)$.

${ }^{\mathrm{a}-\mathrm{d}}$ Means within a row with different superscripts differ $(P \leq 0.05)$.

${ }^{1} \mathrm{SN} / \mathrm{TN}=$ soluble $\mathrm{N} /$ total $\mathrm{N} ; \mathrm{L}^{*}=$ lightness; $\mathrm{a}^{*}=$ redness; $\mathrm{b}^{*}=$ yellowness

${ }^{2} \mathrm{EXT}=$ extensive, where an autochthonous cow breed (Cinisara) was fed mainly at pasture, with hay supplementation at night; INT = intensive, where Brown cows were fed hay and concentrate with a very small proportion of pasture.

${ }^{3} \mathrm{ART}=$ artisanal process using wooden tools; $\mathrm{ADV}=$ advanced process using modern steel equipment.

${ }^{* * *} P \leq 0.0001 ;{ }^{* *} P \leq 0.01 ;{ }^{*} P \leq 0.05 ;+$ indicates $P \leq 0.10$. 
a significant increase in firmness was detected in the compressive stress test between 60 and $120 \mathrm{~d}$ of aging (Table 3).

A significant interaction between cheesemaking technology and ripening stage was noted for soluble $\mathrm{N}$ and its ratio to total $\mathrm{N}$, as well as for the yellow index (b*; Table 3). In fact, ADV cheesemaking produced a marked increase in soluble $\mathrm{N}$ during ripening (Figure 2 ), indicating more pronounced proteolysis that presumably was induced by the lactic acid culture added to the raw milk. The significant interaction for the $b^{*}$ index is explained by the effect of native microflora, which is able to confer a more intense yellow color during ripening than the microflora of the commercial starter (Figure 3; Buffa et al., 2001; Chatelain et al., 2003).

FA Profile. The FA composition (Tables 4 and 5) of cheese fat was mainly affected by farming system, whereas the technology and ripening time did not show relevant effects. Studies on other cheeses also found no effect of technology and ripening time on the FA profile (Jiang et al., 1997; Lin et al., 1999; Gnädig et al., 2004) and attributed cheese differences primarily to the origin of the milk (Lucas et al., 2006) and marginally to the microflora involved in aging process (Jiang et al., 1998).

With respect to health-promoting FA, cheeses from the EXT farm were richer $(P<0.001)$ in vaccenic acid (trans-11 C18:1), rumenic acid (cis-9,trans-11

1.68

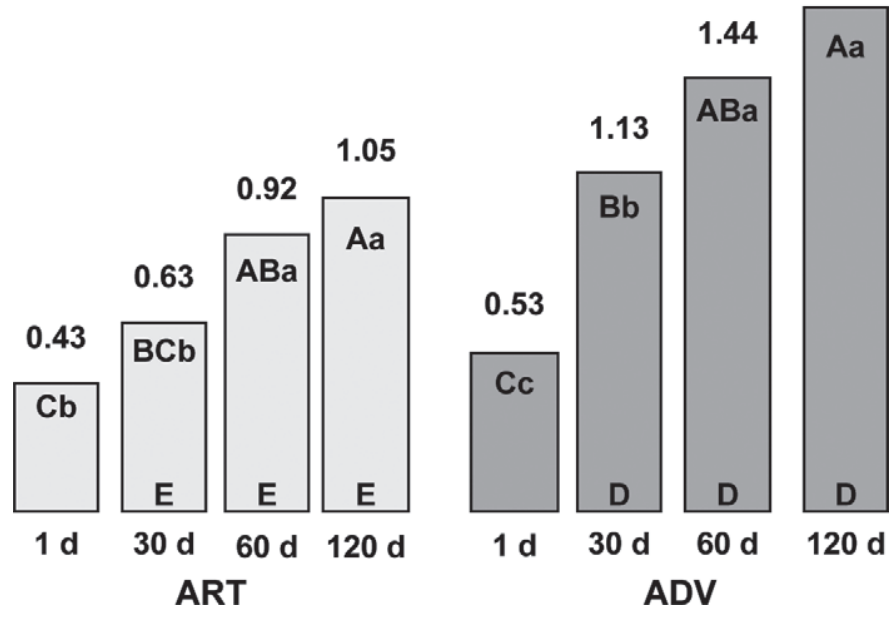

Figure 2. Soluble nitrogen (\%) trend in relation to the ripening time. Significant differences between ripening times within cheesemaking technologies: bars labeled with different uppercase letters $(\mathrm{A}-\mathrm{C})$ indicate differences at $P \leq 0.01$; bars labeled with different lowercase letters $(\mathrm{a}-\mathrm{c})$ indicate differences at $P \leq 0.05$. Significant differences between cheesemaking technologies within ripening times: bars labeled with different letters $\mathrm{E}$ and $\mathrm{D}$ indicate differences at $P \leq 0.01$. ART $=$ artisanal procedure using wooden tools; $\mathrm{ADV}=$ advanced and rapid cheesemaking process with modern steel equipment.

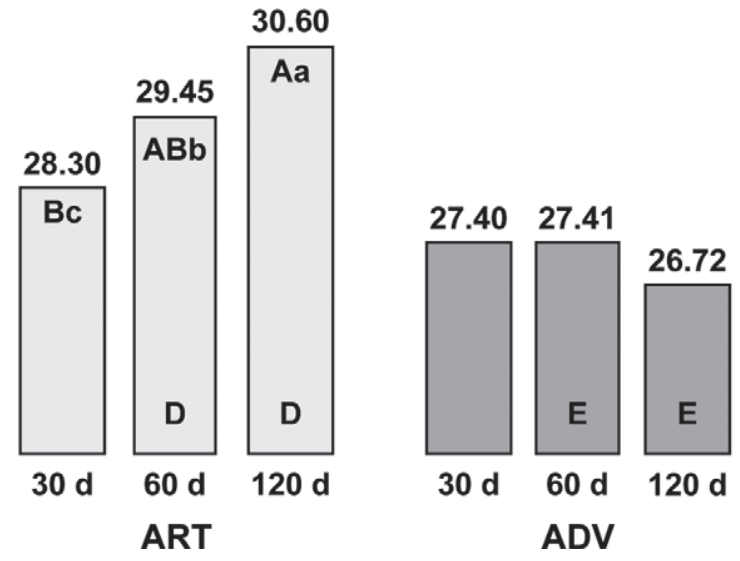

Figure 3. Yellow index $\left(\mathrm{b}^{*}\right)$ trend according to the ripening time. Significant differences between ripening times within cheesemaking technologies: bars labeled with different uppercase letters (A and B) indicate differences at $P \leq 0.01$; bars labeled with different lowercase letters $(\mathrm{a}-\mathrm{c})$ indicate differences at $P \leq 0.05$. Significant differences between cheesemaking technologies within ripening times: bars labeled with different letters $\mathrm{E}$ and $\mathrm{D}$ indicate differences at $P \leq 0.01$. ART $=$ artisanal procedure using wooden tools; $\mathrm{ADV}=$ advanced and rapid cheesemaking process with modern steel equipment.

C18:2), the main isomer of CLA, and $\alpha$-linolenic acid (C18:3n-3), and consequently showed higher total PUFA and n-3 FA values than INT cheeses (Table 5). These results may be explained by the different feeding regimen received by cows, which was mainly based on green forage from natural pasture in the EXT farm and on hay and concentrate in the INT farm. Indeed, pasture-based diets promote an enrichment of CLA and PUFA in dairy products (Chilliard et al., 2007; Ferlay et al., 2008). The higher content of vaccenic acid and rumenic acid in EXT milk, produced by cows of the autochthonous breed grazing at pasture, is confirmed by the observations of Dewhurst et al. (2006) and Lucas et al. (2006) on cows fed natural pasture or a diet rich in green forage rather than grass silage. Moreover, Coppa et al. (2011), studying typical French cheeses produced in different breeding systems, found that cheeses from cows in indoor systems and fed hay were richer in SFA and MUFA; vaccenic and rumenic acid, in contrast, were more abundant in cheese from the milk of cows exploiting pasture, indicating the positive effect of feeding at pasture on consumer health. Moreover, among OBCFA, significantly higher concentrations $(P$ $<0.001$ ) of $\mathrm{C} 15: 0$, iso $\mathrm{C} 15: 0$, anteiso $\mathrm{C} 15: 0, \mathrm{C} 17: 0$, and iso C17:0 (Table 4) were observed in the EXT cheese; these compounds are normally more abundant when cows are fed a diet richer in forage and with a lower starch:NDF ratio (Vlaeminck et al., 2006).

On the contrary, INT cheese showed higher values for linoleic acid (C18:2n-6; $P<0.001)$ and, consequently, MUFA $(P<0.01)$ and n-6 FA $(P<0.001$; 
Table 4. Short- and medium-chain FA composition (\% of FA methyl esters) of cheese

\begin{tabular}{|c|c|c|c|c|c|c|c|c|c|c|c|c|c|c|}
\hline \multirow{2}{*}{ FA } & \multicolumn{2}{|c|}{$\operatorname{Farm}(\mathrm{FM})^{1}$} & \multicolumn{2}{|c|}{$\begin{array}{c}\text { Cheesemaking } \\
\text { technology }(\mathrm{CMT})^{2}\end{array}$} & \multicolumn{4}{|c|}{ Ripening time (RT), d } & \multicolumn{6}{|c|}{ Significance } \\
\hline & $\mathrm{EXT}$ & INT & ADV & ART & 1 & 30 & 60 & 120 & FM & CMT & $\mathrm{RT}$ & $\begin{array}{l}\mathrm{FM} \times \\
\mathrm{CMT}\end{array}$ & $\begin{array}{l}\mathrm{FM} \times \\
\mathrm{RT}\end{array}$ & $\begin{array}{l}\mathrm{CMT} \\
\times \mathrm{RT}\end{array}$ \\
\hline C10:0 & 3.20 & 2.92 & 3.03 & 3.08 & 3.07 & 3.12 & 3.04 & 3.00 & * & NS & NS & NS & NS & NS \\
\hline C11:0 & 0.67 & 0.44 & 0.67 & 0.44 & 1.07 & 0.36 & 0.42 & 0.38 & NS & NS & NS & NS & NS & NS \\
\hline C12:0 & 3.37 & 3.16 & 3.24 & 3.30 & 3.33 & 3.15 & 3.29 & 3.30 & + & NS & NS & NS & NS & NS \\
\hline C13:0 & 0.21 & 0.16 & 0.20 & 0.17 & 0.23 & 0.15 & 0.17 & 0.17 & + & NS & NS & NS & NS & NS \\
\hline iso $\mathrm{C} 14: 0$ & 0.23 & 0.17 & 0.23 & 0.17 & 0.34 & 0.15 & 0.16 & 0.16 & NS & NS & NS & NS & NS & NS \\
\hline C14:0 & 11.02 & 10.43 & 10.71 & 10.75 & 10.67 & 10.50 & 10.87 & 10.86 & * & NS & NS & NS & NS & NS \\
\hline iso $\mathrm{C} 15: 0$ & 0.38 & 0.30 & 0.34 & 0.35 & 0.34 & 0.33 & 0.36 & 0.34 & $* * *$ & NS & NS & + & NS & NS \\
\hline anteiso $\mathrm{C} 15: 0$ & 0.69 & 0.54 & 0.61 & 0.61 & 0.62 & 0.60 & 0.62 & 0.62 & $* * *$ & NS & NS & NS & NS & NS \\
\hline cis-9 C14:1 & 0.73 & 0.86 & 0.79 & 0.81 & 0.82 & 0.71 & 0.83 & 0.82 & $*$ & NS & NS & NS & NS & NS \\
\hline C15:0 & 1.45 & 1.05 & 1.27 & 1.24 & 1.23 & 1.26 & 1.26 & 1.27 & $* * *$ & NS & NS & NS & NS & NS \\
\hline iso $\mathrm{C} 16: 0$ & 0.31 & 0.30 & 0.30 & 0.31 & 0.34 & 0.29 & 0.25 & 0.34 & + & NS & NS & * & NS & NS \\
\hline C16:0 & 26.11 & 29.34 & 27.95 & 27.50 & $26.27^{\mathrm{a}}$ & $28.27^{\mathrm{b}}$ & $28.22^{\mathrm{b}}$ & $28.16^{\mathrm{b}}$ & $* * *$ & NS & $*$ & NS & NS & NS \\
\hline iso $\mathrm{C} 17: 0$ & 0.53 & 0.38 & 0.46 & 0.44 & 0.51 & 0.44 & 0.41 & 0.46 & $* * *$ & NS & NS & NS & NS & NS \\
\hline anteiso $\mathrm{C} 17: 0$ & 0.17 & 0.16 & 0.17 & 0.17 & 0.14 & 0.20 & 0.17 & 0.15 & NS & NS & NS & NS & NS & NS \\
\hline cis-9 C16:1 & 1.02 & 1.17 & 1.09 & 0.10 & 1.10 & 1.08 & 1.15 & 1.04 & $* * *$ & NS & NS & NS & NS & NS \\
\hline C17:0 & 0.82 & 0.64 & 0.73 & 0.73 & 0.70 & 0.76 & 0.73 & 0.74 & $* * *$ & NS & NS & NS & NS & NS \\
\hline cis-10 C17:1 & 0.21 & 0.17 & 0.19 & 0.20 & 0.17 & 0.22 & 0.19 & 0.17 & $*$ & NS & NS & NS & + & NS \\
\hline
\end{tabular}

a,beans within a row with different superscripts differ $(P \leq 0.05)$.

${ }^{1} \mathrm{EXT}=$ extensive, where an autochthonous cow breed (Cinisara) was fed mainly at pasture, with hay supplementation at night; INT $=$ intensive, where Brown cows were fed hay and concentrate with a very small proportion of pasture.

${ }^{2} \mathrm{ART}=$ artisanal process using wooden tools; ADV $=$ advanced process using modern steel equipment.

${ }^{* * *} P \leq 0.001 ;{ }^{*} P \leq 0.05 ;+$ indicates $P \leq 0.10$. 
Table 5. Long-chain FA and groups of FA composition (\% of FA methyl esters) of cheese

\begin{tabular}{|c|c|c|c|c|c|c|c|c|c|c|c|c|c|c|}
\hline \multirow[b]{2}{*}{ Item $^{1}$} & \multicolumn{2}{|c|}{ Farm $(\mathrm{FM})^{2}$} & \multicolumn{2}{|c|}{$\begin{array}{c}\text { Cheesemaking } \\
\text { technology }(\mathrm{CMT})^{3}\end{array}$} & \multicolumn{4}{|c|}{ Ripening time (RT), d } & \multicolumn{6}{|c|}{ Significance } \\
\hline & EXT & INT & ADV & ART & 1 & 30 & 60 & 120 & FM & CMT & RT & $\begin{array}{l}\mathrm{FM} \times \\
\mathrm{CMT}\end{array}$ & $\begin{array}{c}\mathrm{FM} \times \\
\mathrm{RT}\end{array}$ & $\begin{array}{l}\mathrm{CMT} \\
\times \mathrm{RT}\end{array}$ \\
\hline \multicolumn{15}{|l|}{ FA } \\
\hline iso C18 & 0.01 & 0.01 & 0.01 & 0.01 & 0.00 & 0.02 & 0.01 & 0.00 & * & NS & NS & NS & * & NS \\
\hline C18:0 & 11.72 & 9.93 & 10.77 & 10.88 & 10.29 & 10.48 & 11.21 & 11.32 & $* *$ & NS & NS & NS & NS & NS \\
\hline trans-11 C18:1 (VA) & 2.57 & 1.32 & 2.02 & 1.88 & 1.96 & 1.97 & 1.79 & 2.06 & $* * *$ & NS & NS & NS & NS & NS \\
\hline cis-9 C18:1 & 18.75 & 20.76 & 19.9 & 19.5 & 19.46 & 20.84 & 20.46 & 18.03 & + & NS & NS & NS & NS & NS \\
\hline cis-9, cis-12 C18:2n-6 & 1.62 & 2.45 & 1.96 & 2.12 & 1.97 & 2.20 & 2.18 & 1.81 & $* * *$ & NS & NS & NS & NS & NS \\
\hline cis-9,trans-11 C18:2 CLA (RA) & 1.09 & 0.66 & 0.85 & 0.90 & 0.91 & 0.91 & 0.83 & 0.84 & $* * *$ & NS & NS & NS & NS & NS \\
\hline CLA isomers & 0.13 & 0.05 & 0.09 & 0.08 & 0.09 & 0.11 & 0.06 & 0.07 & $* * *$ & NS & NS & NS & NS & NS \\
\hline C18:3n-6 ( $\gamma$-linolenic) & 0.01 & 0.01 & 0.01 & 0.01 & 0.01 & 0.01 & 0.01 & 0.01 & NS & NS & NS & NS & NS & NS \\
\hline C18:3n-3 ( $\alpha$-linolenic) & 1.19 & 0.62 & 0.92 & 0.90 & 0.85 & 1.02 & 0.90 & 0.86 & $* * *$ & NS & NS & NS & NS & NS \\
\hline $\mathrm{C} 20: 0$ & 0.27 & 1.17 & 0.19 & 0.25 & 0.29 & 0.21 & 0.19 & 0.18 & NS & NS & NS & NS & NS & NS \\
\hline C20:5n-3 (EPA) & 0.14 & 0.05 & 0.11 & 0.08 & 0.18 & 0.07 & 0.07 & 0.06 & + & NS & NS & NS & NS & NS \\
\hline $\mathrm{C} 22: 0$ & 0.15 & 0.09 & 0.12 & 0.12 & $0.10^{\mathrm{a}}$ & $0.15^{\mathrm{b}}$ & $0.12^{\mathrm{ab}}$ & $0.12^{\mathrm{ab}}$ & $* * *$ & NS & NS & NS & NS & NS \\
\hline C22:5n-3 (DPA) & 0.06 & 0.02 & 0.02 & 0.05 & 0.04 & 0.06 & 0.02 & 0.03 & $*$ & + & NS & NS & NS & NS \\
\hline $\mathrm{C} 22: 4$ & 0.12 & 0.09 & 0.11 & 0.09 & 0.09 & 0.13 & 0.09 & 0.09 & NS & NS & NS & NS & NS & NS \\
\hline SFA & 66.61 & 66.04 & 66.73 & 65.92 & 66.82 & 65.26 & 66.22 & 67.01 & $\mathrm{NS}$ & NS & NS & NS & NS & NS \\
\hline MUFA & 26.82 & 28.44 & 27.40 & 27.86 & 26.84 & 28.30 & 27.93 & 27.44 & $* *$ & NS & NS & NS & NS & NS \\
\hline PUFA & 4.98 & 4.40 & 4.52 & 4.85 & 4.93 & 4.95 & 4.48 & 4.39 & ** & NS & NS & NS & NS & NS \\
\hline SFA/unsaturated FA & 2.12 & 2.02 & 2.11 & 2.03 & 2.12 & 1.98 & 2.05 & 2.12 & + & NS & NS & NS & NS & NS \\
\hline$\Sigma \mathrm{n}-6$ & 1.72 & 2.65 & 2.08 & 2.29 & 2.16 & 2.33 & 2.29 & 1.95 & $* * *$ & NS & NS & NS & NS & NS \\
\hline$\sum \mathrm{n}-3$ & 1.47 & 0.85 & 1.14 & 1.18 & 1.26 & 1.26 & 1.07 & 1.04 & $* * *$ & NS & NS & NS & NS & NS \\
\hline n-6/n-3 & 1.28 & 3.43 & 2.28 & 2.44 & 2.13 & 2.39 & 2.64 & 2.27 & $* * *$ & NS & NS & NS & NS & NS \\
\hline OBCFA & 6.12 & 4.68 & 5.69 & 5.11 & 6.48 & 4.97 & 5.02 & 5.13 & * & NS & NS & NS & NS & NS \\
\hline HPI & 0.44 & 0.44 & 0.43 & 0.45 & 0.44 & 0.46 & 0.43 & 0.43 & NS & NS & NS & NS & NS & NS \\
\hline
\end{tabular}

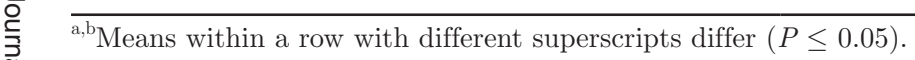

尊 $\quad{ }^{1} \mathrm{VA}=$ vaccenic acid; CLA = conjugated linoleic acid; RA = rumenic acid; EPA = eicosapentaenoic acid; DPA = docosapentaenoic acid; OBCFA = odd- and branched-chain FA; O HPI $=$ health-promoting index $=$ unsaturated FA $/(\mathrm{C} 12: 0+4 \times \mathrm{C} 14: 0+\mathrm{C} 16: 0)($ Chen et al., 2004).

פू. $\quad{ }^{2} \mathrm{EXT}=$ extensive, where an autochthonous cow breed (Cinisara) was fed mainly at pasture, with hay supplementation at night; INT = intensive, where Brown cows were fed hay and concentrate with a very small proportion of pasture.

$\stackrel{\text { 을. }}{3} \mathrm{ART}=$ artisanal process using wooden tools; ADV = advanced process using modern steel equipment.

( $* * * P \leq 0.001 ;{ }^{* *} P \leq 0.01 ;{ }^{*} P \leq 0.05 ;+$ indicates $P \leq 0.10$. 
Table 5). The higher level of linoleic acid in the INT cheeses could be a consequence of the consumption of a concentrate particularly rich in this acid. However, the n-6:n-3 FA ratio was lower $(P<0.001)$ for EXT than INT cheeses (Table 5), whereas the HPI did not differ between farms (Table 5), mainly because of the higher content of linoleic acid in the INT cheeses.

On the whole, the FA profile of EXT cheese demonstrated the health benefits of dairy products from cows reared at pasture, as in the EXT farm. Moreover, the results of this trial confirm those of the preexperimental trial, in which cheeses from TRD farming systems were healthier because they were richer in OBCFA, CLA, and unsaturated FA.

The controlled conditions created in this trial, designed to avoid all possible external factors that could affect the FA profile of dairy products, have demonstrated that the feeding of animals is the most important factor in determining the FA profile of milk and cheese, as previously reported in the literature (Couvreur et al., 2006; Chilliard et al., 2007; Ferlay et al., 2008).

Sensory Analysis. Regarding the sensory profile of Caciocavallo Palermitano (Table 6; Figures 4 and 5), cheeses from EXT milk had a smoother paste with a sweeter, less bitter and salty, and more acidic taste. Similarly, Carpino et al. (2004) noted that the taste of Ragusano cheese from the milk of cows fed fresh forage in a Sicilian natural pasture was sweeter and more pungent and less bitter, salty, and acidic.

The greater bitterness in INT cheeses, regardless of the technology and time of aging, may be related to the higher soluble $\mathrm{N}$ measured in cheeses from this farming system (Table 3), in accordance with Fallico et al. (2005), who found a higher degree of bitterness in Ragusano cheese with higher soluble N content; those authors attributed this relationship to an unbalanced level of primary and secondary proteolysis. The more pronounced bitter taste of Ragusano cheese could be a consequence of differences in cheesemaking technology or salting brine, which in turn, influence microbial activity during aging (Fallico et al., 2005); nevertheless, it is reasonable to assume that, in this trial, the higher urea content in the INT milk (Table 1), linked to cow protein intake, may have had an effect on the final cheese taste. This higher urea content in the milk should have increased the amount of soluble $\mathrm{N}$ and, as a consequence, the bitterness of cheese. However, this hypothesis contradicts the observations of Martin et al. (1997), who found that Reblochon cheese made from milk richer in urea was less bitter and sweeter than cheese made from milk lower in urea. The same authors suggested that urea is able to directly influence the ripening process and strongly modifies the final taste of cheese. In the current trial, the bitter taste decreased significantly during ripening, from 30 to 60 $\mathrm{d}$ of aging; this reduction was more pronounced in INT cheese, especially if made by the ART process (Figure 5), revealing the significant interaction between cheesemaking technology and ripening time that emerged for bitter taste (Table 6).

The ART cheese had fewer holes than ADV cheese (Table 6). Because the 2 cheesemaking processes were applied to the same raw milk, this effect on the occurrence of holes should be attributed to the different microbiological activities developed under the control of the different types of lactic flora implicated (Fox et al., 2004). The holes were more evident at $30 \mathrm{~d}$ only in ADV cheeses from the INT farm, whereas after $60 \mathrm{~d}$ of aging, holes were prevalent in ADV cheese from both farms (Figure 4).

The ADV cheese was also smoother and more unctuous and elastic, characteristics that were more evident in 30- than 60-d ripened cheeses (Table 6 and Figure 4). With regard to the cheesemaking technologies, the "elastic" descriptor was related to the compressive stress (Table 3), with a higher value for ADV cheese, which was less compact than ART cheese and thus more elastic and soft.

The descriptors of taste - bitter, salty, and acidichad higher values for ADV than for ART cheeses (Table 6 ), with more distinctive differences in the cheeses aged $60 \mathrm{~d}$ (Figure 5). Most of the salty taste of ADV cheese (Table 6 and Figure 5) was strictly due to its higher percentage of salt (Table 3). This was attributable to the specific technology, which left the paste less compact and with more moisture (Table 3) and, therefore, promoted the osmosis of salt from saturated brine into the cheese.

The descriptor representing the typical piquancy of Caciocavallo Palermitano cheese had a slightly higher value in $\mathrm{ART}$ than $\mathrm{ADV}$ cheeses, which may have been due to the action of the native lactic flora involved in cheese making that were present on the surface of the artisanal wooden tools. Accordingly, in other manufacturing processes using wooden tools, such as that of the Protected Designation of Origin Piacentinu Ennese (Carpino et al., 2008), different volatile fingerprints have been identified. When milk is poured into the wooden vats used in these processes, the lactic acid bacteria forming a biofilm on the vat pass into the milk and produce different tastes in dairy products. During aging, the piquant notes increased, although not significantly, because of the enzymatic activity of lactic acid bacteria.

The ripening time affected cheese textures; at $60 \mathrm{~d}$, cheeses were harder and less elastic to the touch. Additionally, more ripened cheeses were less intensely sweet and bitter (Table 6). 
Table 6. Sensory analysis of Caciocavallo Palermitano cheese: mean values of main visual, tactile, and taste descriptors ${ }^{1}$

\begin{tabular}{|c|c|c|c|c|c|c|c|c|c|c|c|c|}
\hline \multirow[b]{2}{*}{ Item } & \multicolumn{2}{|c|}{$\operatorname{Farm}(\mathrm{FM})^{2}$} & \multicolumn{2}{|c|}{$\begin{array}{c}\text { Cheesemaking } \\
\text { technology }(\mathrm{CMT})^{3}\end{array}$} & \multicolumn{2}{|c|}{ Ripening time (RT), d } & \multicolumn{6}{|c|}{ Significance } \\
\hline & EXT & INT & $\mathrm{ART}$ & $\mathrm{ADV}$ & 30 & 60 & FM & $\mathrm{CMT}$ & $\mathrm{RT}$ & $\begin{array}{l}\mathrm{FM} \times \\
\mathrm{CMT}\end{array}$ & $\begin{array}{c}\mathrm{FM} \times \\
\mathrm{RT}\end{array}$ & $\begin{array}{l}\mathrm{CMT} \\
\times \mathrm{RT}\end{array}$ \\
\hline \multicolumn{13}{|l|}{ Visual examination } \\
\hline \multicolumn{13}{|l|}{ Light yellow color of } \\
\hline Under-rind & 4.39 & 4.16 & 4.06 & 4.50 & 4.27 & 4.29 & NS & NS & NS & $* *$ & $* *$ & $* * *$ \\
\hline Paste & 3.16 & 3.25 & 3.28 & 3.14 & 3.13 & 3.29 & NS & NS & NS & NS & NS & NS \\
\hline Holes & 2.21 & 2.81 & 1.43 & 3.59 & 3.23 & 1.79 & NS & $* * *$ & $* *$ & $* *$ & $* * *$ & $*$ \\
\hline Under-rind thickness & 4.08 & 3.61 & 3.73 & 3.94 & 3.72 & 3.97 & + & NS & NS & NS & $* *$ & NS \\
\hline \multicolumn{13}{|l|}{ Tactile examination } \\
\hline Smooth & 4.99 & 3.41 & 3.71 & 4.69 & 4.24 & 4.16 & $* * *$ & ** & NS & NS & NS & + \\
\hline Hard & 4.74 & 4.48 & 4.54 & 4.67 & 3.55 & 5.68 & NS & NS & $* * *$ & NS & NS & NS \\
\hline Unctuous & 3.26 & 3.64 & 3.17 & 3.73 & 3.65 & 3.24 & NS & $*$ & NS & NS & NS & NS \\
\hline Elastic & 3.62 & 3.32 & 3.01 & 3.94 & 3.80 & 3.15 & NS & $* *$ & $*$ & NS & NS & $*$ \\
\hline \multicolumn{13}{|l|}{ Taste } \\
\hline Sweet & 4.23 & 3.69 & 4.03 & 3.84 & 4.55 & 3.37 & $* *$ & NS & $* * *$ & $* *$ & $* * *$ & $* * *$ \\
\hline Bitter & 3.84 & 4.78 & 4.01 & 4.61 & 4.82 & 3.79 & $* * *$ & $* *$ & $* * *$ & $* * *$ & $* * *$ & * \\
\hline Salty & 5.12 & 5.64 & 4.96 & 5.80 & 5.31 & 5.45 & $*$ & $* * *$ & NS & NS & NS & + \\
\hline Acid & 5.19 & 4.33 & 4.29 & 5.22 & 4.70 & 4.82 & $* * *$ & $* * *$ & NS & $*$ & $* * *$ & NS \\
\hline Piquant & 3.64 & 3.66 & 3.30 & 3.00 & 2.89 & 3.41 & NS & * & NS & + & NS & + \\
\hline
\end{tabular}

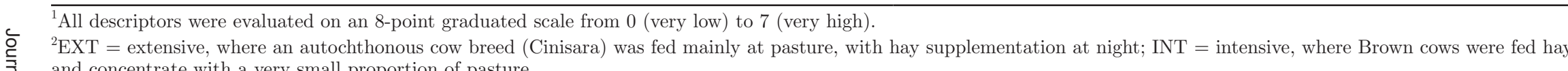

$\quad{ }^{3} \mathrm{ART}=$ artisanal process using wooden tools; $\mathrm{ADV}=$ advanced process using modern steel equipment.

ㄱ. $* * * P \leq 0.001 ; * * P \leq 0.01 ; * P \leq 0.05 ;+$ indicates $P \leq 0.10$. 


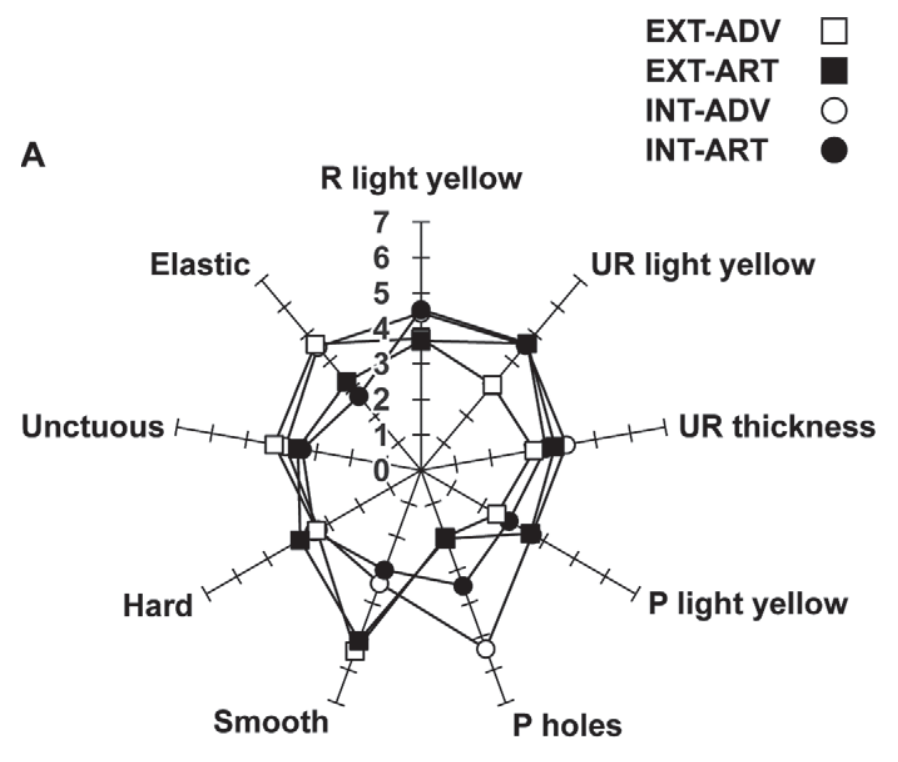

B

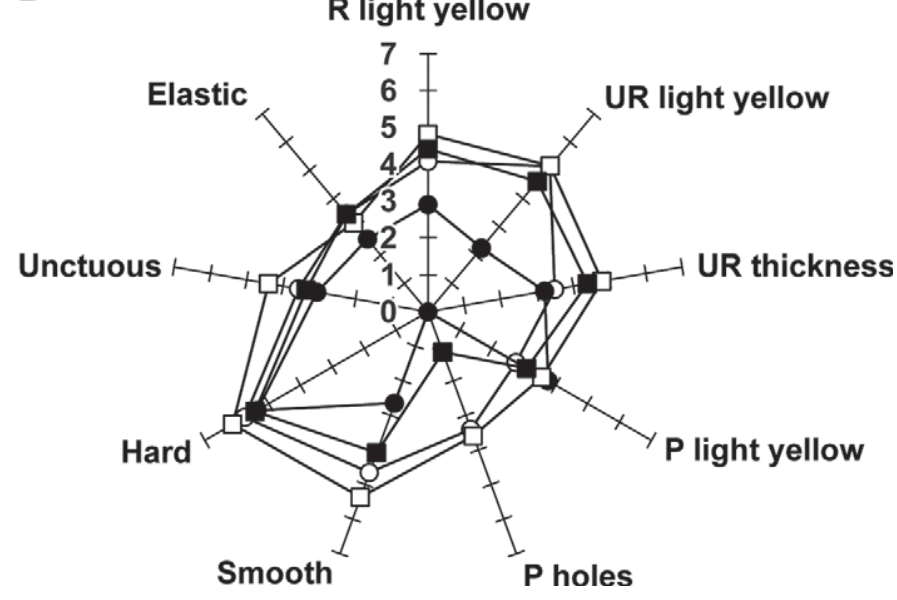

Figure 4. Visual and tactile descriptors of cheeses at 30 (A) and 60 (B) d of ripening. Descriptors were evaluated on an 8-point graduated scale from 0 (very low) to 7 (very high). EXT $=$ extensive milk, obtained from a farm where an autochthonous cow breed (Cinisara) was fed mainly at pasture, with hay supplementation at night; INT = intensive milk, obtained from Brown cows fed hay and concentrate with a very small proportion of pasture; $\mathrm{ADV}=$ advanced and rapid cheesemaking process with modern steel equipment; ART $=$ artisanal procedure using wooden tools; $\mathrm{R}=$ rind; $\mathrm{UR}=$ under-rind; $\mathrm{P}=$ paste.

\section{CONCLUSIONS}

In the preexperimental study, the farming system had a strong influence on the FA composition. In particular, TRD systems led to enrichment of unsaturated FA as well as of cis-9,trans-11 C18:2 CLA and OBCFA, which are known to be beneficial to human health. In the experimental trial, the chemical, physical, and sensory traits of Caciocavallo Palermitano cheese were highly affected by either the farming system or the cheesemak-

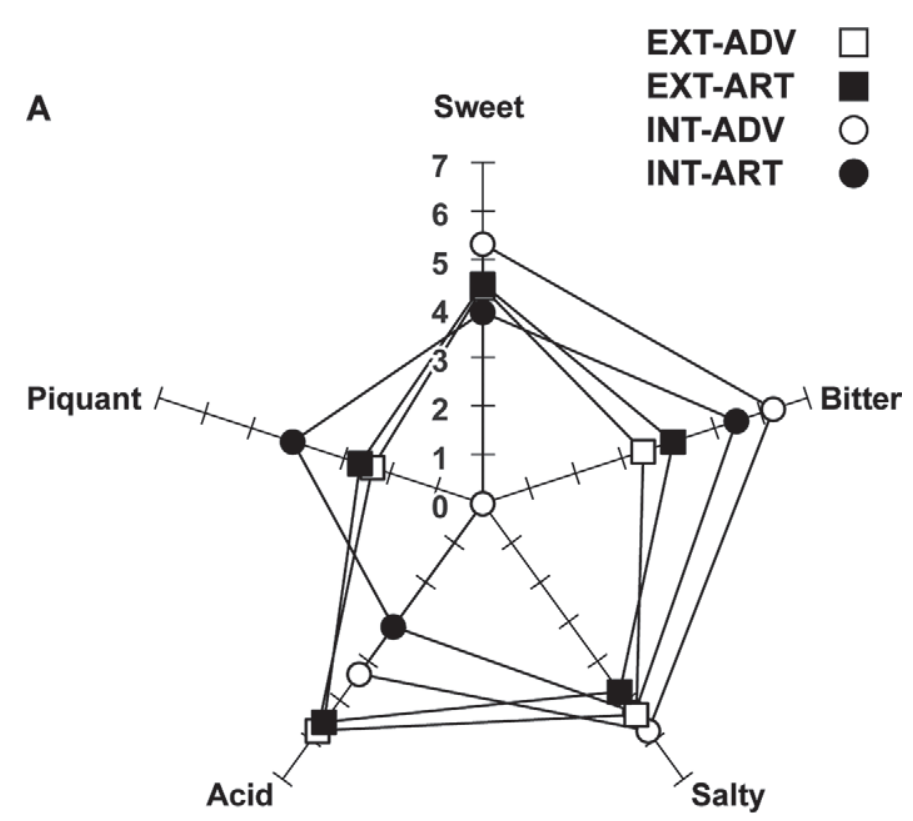

B Sweet

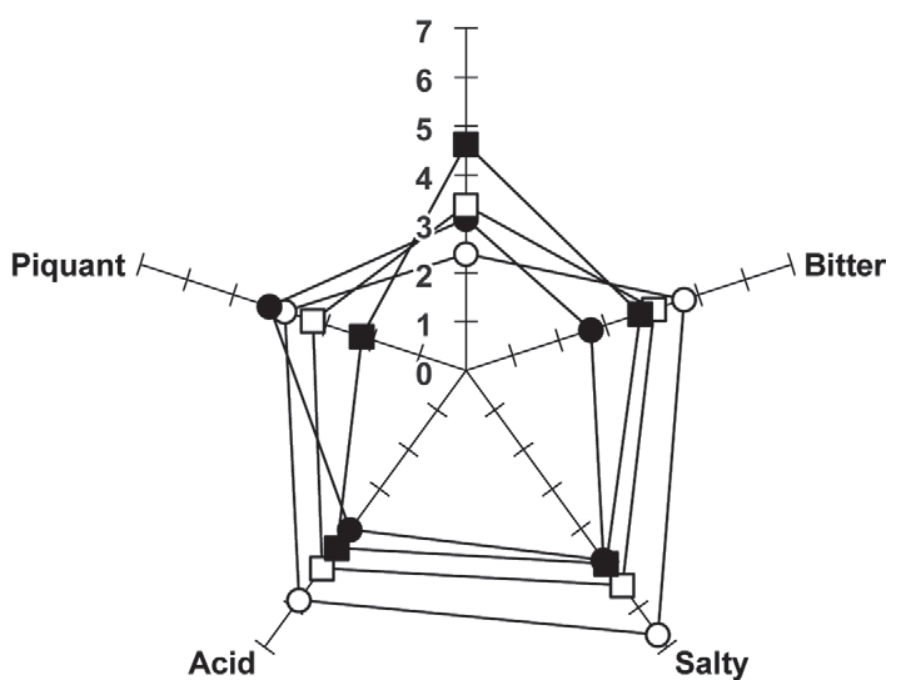

Figure 5. Taste descriptors of cheeses at 30 (A) and 60 (B) d of ripening. Descriptors were evaluated on an 8-point graduated scale from 0 (very low) to 7 (very high). EXT = extensive milk, obtained from a farm where an autochthonous cow breed (Cinisara) was fed mainly at pasture, with hay supplementation at night; INT = intensive milk, obtained from Brown cows fed hay and concentrate with a very small proportion of pasture; ADV = advanced and rapid cheesemaking process with modern steel equipment; ART $=$ artisanal procedure using wooden tools.

ing technology. The extensive farming system, in which autochthonous cow breeds are fed a pasture-based diet, produced milk that was richer in casein and lower in somatic cells compared with the intensive system. The extensive milk produced cheese - in higher yield - that had more protein, less fat, a less intense yellow color, 
and a better sensory profile, characterized by a smoother paste and sweeter, less bitter and salty, and more acidic taste. The cheeses made through traditional technology based on the use of artisanal wooden tools and the action of native lactic microflora were produced in lower yield and had more fat, a harder, more compact paste, and fewer holes than cheeses manufactured with the advanced technology. Artisanal cheeses were less bitter, salty, and acidic than ADV cheeses. Moreover, compared with the selected microflora used to produce ADV cheeses, the native lactic acid bacteria used in the artisanal approach induced slower proteolysis and a more yellow color during aging; the native bacteria also influenced the cheese sensory profile, particularly by reducing the cheese's bitter taste and increasing the characteristic piquant note. In line with the preexperimental results, the pasture-based diet of extensive farming systems led to cheeses with an FA profile that is more beneficial to human health, richer in PUFA, $\mathrm{n}-3$, and OBCFA, as well as in cis-9,trans-11 C18:2 CLA. The results demonstrated that, despite a lower cheese yield, an EXT farming system and TRD and ART cheesemaking technology are determinant in giving to Caciocavallo Palermitano cheese a higher fat content and a firmer paste, and sensory characteristics that are typical of this cheese.

\section{ACKNOWLEDGMENTS}

This research was conducted within the project PROLACTIS funded by the Regione Siciliana, Italy.

\section{REFERENCES}

Alabiso, M., A. Di Grigoli, A. Bonanno, M. L. Alicata, M. Bongarrà, G. Calagna, and A. Console. 2000. Effetto del diverso comportamento al rilascio del latte sulla produzione quanti-qualitativa in bovine Modicane (Effect of the different behaviour to milk release on milk yield and quality in Modicana cows). Pages 457-458 in Proc. of the 54th Congress of Società Italiana delle Scienze Veterinarie (S.I.S.Vet.), Riva del Garda (TN), Italy.

Banni, S., E. Murru, E. Angioni, G. Carta, and M. P. Melis. 2002. Conjugated linoleic acid isomers (CLA): Good for everything? Sci. Aliments 22:371-380.

Bauman, D. E., and J. M. Griinari. 2001. Regulation and nutritional manipulation of milk fat: Low-fat milk syndrome. Livest. Prod. Sci. 70:15-29.

Belury, M. A. 2002. Dietary conjugated linoleic acid in health: Physiological effects and mechanisms of action. Annu. Rev. Nutr. 22:505-531.

Bonanno, A. 2006. I prodotti caseari di qualità della Provincia di Palermo. I formaggi tradizionali (Cheese of high quality in the Province of Palermo. The traditional cheese). Pages 151-288 in Mangio sicuro mangio meglio, qualità alimentare è qualità della vita (I eat safe, I eat better, quality of food is quality of life). Provincia Regionale di Palermo, Assessorato Agricoltura, Caccia e pesca. http:// www.provincia.palermo.it/provpalermo/allegati/575/Parte_5.pdf.

Buffa, M. N., A. J. Trujillo, M. Pavia, and B. Guamis. 2001. Changes in textural, microstructural and colour characteristics during rip- ening of cheese made from raw, pasteurized or high-pressure-treated goats' milk. Int. Dairy J. 11:927-934.

Bonanno, A., A. Di Grigoli, G. Tornambè, B. Formoso, M. L. Alicata, G. Procida, P. Manzi, S. Marconi, and L. Pizzoferrato. 2004. Effects of feeding regime on nutritional and aromatic characteristics of Caciocavallo Palermitano cheese. Pages 43-50 in Atti de Cheese Art 2004-Proc. of 6th International Meeting on Mountain Cheeses. Consorzio Ricerca Filiera Lattiero-Casearia (CoRFiLaC), Ragusa, Italy.

Campo, P., G. Licitra, R. Gelsomino, L. Corallo, S. Carpino, and D. M. Barbano. 1999. Composition of milk from Modicana and other breeds of dairy cattle in Sicily. Milchwissenschaft 54:421-480.

Carpino, S., J. Horne, C. Melilli, G. Licitra, D. M. Barbano, and P. J. Van Soest. 2004. Contribution of native pasture to the sensory properties of Ragusano cheese. J. Dairy Sci. 87:308-315.

Carpino, S., T. Rapisarda, G. Belvedere, and G. Licitra. 2008. Volatile fingerprint of Piacentinu cheese produced with different tools and type of saffron. Small Rumin. Res. 79:16-21.

Chatelain, Y., J. Aloui, D. Guggisberg, and J. O. Bosset. 2003. La couleur du lait et des produits laitiers et sa mesure: Un article de synthèse (1972-2002). Mitt. Lebensmitteluntersuchung Hyg. 94:461-488.

Chen, S., G. Bobe, S. Zimmerman, E. G. Hammond, C. M. Luhman, T. D. Boylston, A. E. Freeman, and D. C. Beitz. 2004. Physical and sensory properties of dairy products from cows with various milk fatty acid compositions. J. Agric. Food Chem. 52:3422-3428.

Chilliard, Y., A. Ferlay, and M. Doreau. 2001. Effect of different types of forages, animal fat or marine oils in cow's diet on milk fat secretion and composition, especially conjugated linoleic acid (CLA) and polyunsaturated fatty acids. Livest. Prod. Sci. 70:31-48.

Chilliard, Y., F. Glasser, A. Ferlay, L. Bernard, J. Rouel, and M. Doreau. 2007. Diet, rumen biohydrogenation and nutritional quality of cow and goat milk fat. Eur. J. Lipid Sci. Technol. 109:828 855

Combellas, J., and M. Tesorero. 2003. Cow-calf relationship during milking and its effect on milk yield and calf live weight gain. Livestock Research for Rural Development (15) 3. http://www.lrrd. org/lrrd15/3/comb153.htm.

Coppa, M., A. Ferlay, F. Monsallier, I. Verdier-Metz, P. Pradel, R. Didienne, A. Farruggia, M. C. Montel, and B. Martin. 2011. Milk fatty acid composition and cheese texture and appearance from cows fed hay or different grazing systems on upland pastures. J. Dairy Sci. 94:1132-1145.

Coulon, J.-B., A. Delacroix-Buchet, B. Martin, and A. Pirisi. 2004. Relationships between ruminant management and sensory characteristics of cheeses: A review. Lait 84:221-241.

Couvreur, S., C. Hurtaud, C. Lopez, L. Delaby, and J. L. Peyraud. 2006. The linear relationship between the proportion of fresh grass in the diet of cows, milk fatty acid composition, and butter properties. J. Dairy Sci. 89:1956-1969.

Depledt, F., and SSHA (Société Scientifique d'Hygiène Alimentaire). 2009. Evaluation sensorielle: Manuel méthodologique. Tec \& DocLavoisier, Paris.

Dewhurst, R. J., K. J. Shingfield, M. R. F. Lee, and N. D. Scollan. 2006. Increasing the concentrations of beneficial polyunsaturated fatty acids in milk produced by dairy cows in high-forage systems. Anim. Feed Sci. Technol. 131:168-206.

Di Grigoli, A., A. Bonanno, G. F. Cifuni, G. Tornambé, and M. L. Alicata. 2008. Effetto del regime alimentare delle bovine sulla composizione in acidi grassi del formaggio Caciocavallo Palermitano (Effects of feeding regime of dairy cows on fatty acids composition of Caciocavallo Palermitano cheese). Scienza e Tecnica Lattiero Casearia 59:457-461.

Fallico, V., P. L. H. McSweeney, J. Horne, C. Pediliggieri, J. A. Hannon, S. Carpino, and G. Licitra. 2005. Evaluation of bitterness in Ragusano cheese. J. Dairy Sci. 88:1288-1300.

Fallico, V., P. L. H. McSweeney, K. J. Siebert, J. Horne, S. Carpino, and G. Licitra. 2004. Chemometric analysis of proteolysis during ripening of Ragusano cheese. J. Dairy Sci. 87:3138-3152.

Ferlay, A., C. Agabriel, C. Sibra, C. Journal, B. Martin, and Y. Chilliard. 2008. Tanker milk variability in fatty acids according to farm 
feeding and husbandry practices in a French semi-mountain area. Dairy Sci. Technol. 88:193-215.

Ferlay, A., B. Martin, P. Pradel, J. B. Coulon, and Y. Chilliard. 2006. Influence of grass-based diets on milk fatty acid composition and milk lipolytic system in Tarentaise and Montbéliarde cow breeds. J. Dairy Sci. 89:4026-4041.

Fox, P. F., P. L. H. McSweeney, T. M. Cogan, and T. P. Guinee. 2004. Page 468 in Cheese: Chemistry, Physics and Microbiology. 3rd ed. Elsevier Academic Press, London UK.

Gnädig, S., J.-F. Chamba, E. Perreard, S. Chappaz, J.-M. Chardigny, R. Rickert, H. Steinhart, and J.-L. Sébédio. 2004. Influence of manufacturing conditions on the conjugated linoleic acid content and the isomer composition in ripened French Emmental cheese. J. Dairy Res. 71:367-371.

Guastella, A. M., D. Marletta, S. Bordonaro, and G. D'Urso. 2006. Sicilian cattle breeds and typical cheeses. Italus Hortus 13:836-838.

Horne, J., S. Carpino, L. Tuminello, T. Rapisarda, L. Corallo, and G. Licitra. 2004. Differences in volatile, and chemical microbial and sensory characteristics between artisanal and industrial Piacentinu Ennese cheese. Int. Dairy J. 15:605-617.

IDF (International Dairy Federation). 1964a. Determination of the protein content of processed cheese products. Standard FIL-IDF 25:1964. International Dairy Federation, Brussels, Belgium.

IDF (International Dairy Federation). 1964b. Determination of the ash content of processed cheese products. Standard FIL-IDF 27:1964. International Dairy Federation, Brussels, Belgium.

IDF (International Dairy Federation). 1972. Cheese-determination of chloride content. Standard FIL-IDF 17A:1972. International Dairy Federation, Brussels, Belgium.

IDF (International Dairy Federation). 1982. Cheese and processed cheese product. Determination of the total solids content. Standard FIL-IDF 4A:1982. International Dairy Federation, Brussels, Belgium.

IDF (International Dairy Federation). 1986. Cheese and processed cheese product. Determination of fat content-gravimetric method (Reference method). Standard FIL-IDF 5B:1986. International Dairy Federation, Brussels, Belgium.

Jiang, J., L. Björck, and R. Fondén. 1997. Conjugated linoleic acid in Swedish dairy products with special reference to the manufacture of hard cheeses. Int. Dairy J. 7:863-867.

Jiang, J., L. Björck, and R. Fondén. 1998. Production of conjugated linoleic acid by dairy starter cultures. J. Appl. Microbiol. 85:95102.

Licitra, G., R. W. Blake, P. A. Oltenacu, S. Barresi, S. Scuderi, and P. J. Van Soest. 1998. Assessment of the dairy production needs of cattle owners in southeastern Sicily. J. Dairy Sci. 81:2510-2517.

Lin, H., T. D. Boylston, L. O. Luedecke, and T. D. Shultz. 1999. Conjugated linoleic acid content of Cheddar-type cheeses as affected by processing. J. Food Sci. 64:874-878.

Loor, J. J., J. H. Herbein, and C. E. Polan. 2002. Trans18:1 and 18:2 isomers in blood plasma and milk fat of grazing cows fed a grain supplement containing solvent-extracted or mechanically extracted soybean meal. J. Dairy Sci. 85:1197-1207.

Lucas, A., E. Rock, J.-F. Chamba, I. Verdier-Metz, P. Bracket, and J.-B. Coulon. 2006. Respective effects of milk composition and the cheese-making process on cheese compositional variability in components of nutritional interest. Lait 86:21-41.

MAF (Ministero dell'Agricoltura e delle Foreste). 1986. Decreto ministeriale 21/4/1986. Approvazione dei metodi ufficiali di analisi per i formaggi (Italian official methods of cheeses analysis), no. 8, page 15. Supplemento ordinario alla Gazzetta Ufficiale della Repubblica Italiana (GURI), no. 229 del 2/10/1986.

Martin, B., J. B. Coulon, J. F. Chamba, and C. Bugaud. 1997. Effect of milk urea content on characteristics of matured Reblochon cheeses. Lait 77:505-514.
Martin, B., D. Pomiès, P. Pradel, I. Verdier-Metz, and B. Rémond. 2009. Yield and sensory properties of cheese made with milk from Holstein or Montbéliarde cows milked twice or once daily. J. Dairy Sci. 92:4730-4737.

McGuire, M. A., and M. K. McGuire. 2000. Conjugated linoleic acid (CLA): A ruminant fatty acid with beneficial effects on human health. In Proc. Am. Soc. Anim. Sci. Annu. Mtg. 1999. http:// www.agron.iastate.edu/courses/agron515/McGuireCLA.pdf.

Nozière, P., B. Graulet, A. Lucas, B. Martin, P. Grolier, and M. Doreau. 2006. Carotenoids for ruminants: From forages to dairy products. Anim. Feed Sci. Technol. 131:418-450.

Panari, G., P. Mariani, A. Summer, R. Guidetti, and M. Pecorari. 2003. Change of the composition and evolution of the proteolysis of Parmigiano-Reggiano cheese during ripening as regards the shape (outer and inner part) of the wheel. (Variazione della composizione e andamento della proteolisi del Parmigiano-Reggiano nel corso della maturazione in riferimento al profilo (centro e periferia) della forma.) Scienza e Tecnica Lattiero Casearia 54:199-212.

SAS Institute. 2004. SAS/STAT Qualification Tools User's Guide. Version 9.1.2. SAS Institute Inc., Cary, NC.

Schepers, A. J., and R. G. M. Meijer. 1998. Evaluation of the utilization of dietary nitrogen by dairy cows based on urea concentration in milk. J. Dairy Sci. 81:579-584.

Settanni, L., A. Di Grigoli, G. Tornambé, V. Bellina, N. Francesca, G. Moschetti, and A. Bonanno. 2012. Persistence of wild Streptococcus thermophilus strains on wooden vat and during the manufacture of a traditional Caciocavallo type cheese. Int. J. Food Microbiol. 155:73-81.

Todaro, M., N. Francesca, S. Reale, G. Moschetti, F. Vitale, and L. Settanni. 2011. Effect of different salting technologies on the chemical and microbiological characteristics of PDO Pecorino Siciliano cheese. Eur. Food Res. Technol. 233:931-940.

Tornambé, G., A. Cornu, I. Verdier-Metz, P. Pradel, N. Kondjoyan, G. Figueredo, S. Hulin, and B. Martin. 2008. Addition of pasture plant essential oil in milk: Influence on chemical and sensory properties of milk and cheese. J. Dairy Sci. 91:58-69.

Tornambè, G., A. Di Grigoli, M.-L. Alicata, C. De Pasquale, and A. Bonanno. 2009. Comparing quality characteristics of "Caciocavallo Palermitano" cheese from traditional and intensive production systems Pages 153-156 in Proceeding of the 15th Meeting of the FAO-CIHEAM Mountain Pastures Network, Les Diablerets, Switzerland. http://fao09.adcf.ch/attachments/File/proceeding.pdf.

Tornambé, G., A. Ferlay, A. Farruggia, Y. Chilliard, P. Loiseau, J. P. Garel, and B. Martin. 2007. Effet de la diversité floristique des pâturages de montagne sur le profil en acides gras et les caractéristiques sensorielles des laits. Rencontres Recherches Ruminants $14: 333-336$.

Tornambé, G., A. Lucas, I. Verdier-Metz, S. Hulin, C. Agabriel, and B. Martin. 2005. Effect of production systems on a sensory characteristics of PDO Cantal cheese. Ital. J. Anim. Sci. 4(Suppl. 2):250-252.

Tosi, F., S. Sandri, G. Tedeschi, M. Malacarne, and E. Fossa. 2008 Variazioni di composizione e proprietà fisico-chimiche del Parmigiano-Reggiano durante la maturazione e in differenti zone della forma (Variations of composition and physico-chemical properties of Parmigiano-Reggiano cheese throughout ripening in different zones of the cheese wheel). Scienza e Tecnica Lattiero Casearia 59:507-528.

Vlaeminck, B., V. Fievez, A. R. J. Cabrita, A. J. M. Fonseca, and R. J. Dewhurst. 2006. Factors affecting odd- and branched-chain fatty acids in milk: A review. Anim. Feed Sci. Technol. 131:389-417. 